\title{
The Studies of Chinese Minnow (Rhynchocypris oxycephalus) and Amur Minnow (Rhynchocypris lagowskii): A Review
}

\author{
In-Seok Park* \\ Division of Convergence on Marine Science, College of Ocean Science and Engineering, Korea Maritime \& Ocean University, \\ Republic of Korea
}

*Corresponding author: In-Seok Park, Division of Convergence on Marine Science, College of Ocean Science and Engineering, Korea Maritime \& Ocean University, Republic of Korea

\begin{tabular}{|c|c|}
\hline ARTICLE INFO & ABSTRACT \\
\hline Received: March 18, 2021 & $\begin{array}{l}\text { The Rhynchocypris minnows (Teleostei: Cyprinidae) are typically small cold water } \\
\text { fish, mainly distributed in Asia. This paper briefly reviews the studies of Chinese minnow }\end{array}$ \\
\hline Published: 幽 March 24, 2021 & $\begin{array}{l}\text { (Rhynchocypris oxycephalus) and Amur minnow (Rhynchocypris lagowskii) based on } \\
\text { the studies collected so far and could form the basis for a wide category of researches }\end{array}$ \\
\hline
\end{tabular}

alus) and Amur Minnow (Rhynchocypris lagowskii): A Review. Biomed J Sci \& Tech Res 34(5)-2021. BJSTR. MS.ID.005600.

\section{Introduction}

The Chinese minniw, Rhynchocypris oxycephalus (Sauvage \& Dabry de Thiersant, 1874; synonyms: Lagowskiella czekanowskii suifunensis; Leuciscus costatus; Moroco oxycephalus; Phoxinus czekanowskii suifunensis; Phoxinus lagowskii oxycephalus; Phoxinus oxycephalus; Phoxinus percnurus suifunensis; Pseudophoxinus oxycephalus) is an Asian species of small freshwater cyprinid fish [1,2]. It is endemic species of East Asia, widely distributed from southern China to most parts of the Korean Peninsula and western Japan [3-9]. They live in cold, running, or still (but well oxygenated) waters, generally inhabiting stream headwaters at high altitude $[7,10,11]$ : The Amur minnow or Lagowski's minnow (Rhynchocypris lagowskii: Dybowski, 1869; synonyms: Lagowskiella lagowskii; Moroco yamamotis; Phoximus lagowskii; Pseudaspis bergi; Rhynchocypris variegata)is an Asian species of small freshwater cyprinid fish [1,2]. It is found from the Lena and Amur rivers in the morth to the Yangtze in China in the south [12]. The aim of my work is to carry out a critical review of the studies concerning a wide category of zootaxy, reproduction \& development, ecology, starvation, environmental biology, and techniques for R. oxycephalus and $R$. lagowskii, which were done over a period of 21 years from 1998 to 2019.

\section{Zootaxy (Refer to Appendix)}

\section{Rhynchocypris oxycephalus:}

Two species of Moroco oxycephalus and M. lagowskii were studied by Min and Yang [13] to examine pattermsof genic variation and morphological differences within and between populations of two species, and to clarify their taxonomic status and geographic distribution. The results obtained from the study of Min and Yang [13] are as this: 1 . The number of scales above lateral line (SAL) was the key character to classify these species. On the average. $M$. lagowskii had 22 or more SAL whereas M. oxycephalus had 20 or less. Previously known character of the position of dorasal fin was found to be not appropriate to distinguish them; 2. Five loci, Gp, Est-1, Est - 2, Est - 3, and Got - 1, showed fixed difference electrophoretically between two species and these could be used as genetic markers to identify them; 3 . The degree of genic variation of $M$. oxycephalus was for fold higher $(\bar{H}=0.032)$ than that of M. lagowskii $(\vec{H}=0.008)$ but both species were far less than the average genic variation of 
freshwater fish in general; 4. Roger' genic similarity coefficients between two species were $\bar{S}=0.692$ and their presumed divergent time was estimated to be about 1.8 million years ago. Detailed survey of the geographic distribution of these species revealed that M. lagowskii was distributed in northeastern part of South Korea (Ganseong, Gangreung, Wangsan, and Oggye) and M. oxycephalus was occupied rest of the peninsula. The distance between Oggye, the southern limit of $M$. lagowskii distribution, and Samwha (near Samcheog), the northern limit of M. oxycephalus, was about $15 \mathrm{~km}$ apart and no sympatry was found in between.

The taxonomic status of Moroco lagowskii and M. oxycephalus, a pair of sibling species inhabiting in Korean fresh waters, has been unclear up to date [14]. Recently a sympatric area of these species was found [14]. Yang and Min [14] clarified their specific status by analyzing specimens collected from the sympatric area of these species. Isozyme analysis and morphometric comparison were performed [14]. Among 26 loci screened, 6 loci (Aco, Est-2, E-X, Gp3, Ipo, $M e$ ) showed fixed allelic difference between them and these loci could be used as genetic markers to distinguish them. Isozyme analysis indicates that no hybridization occurs and therefore it is assumed that isolating mechanism is completed and they are distinct species. The mean number of scales above lateral line (SAL) of M. lagowskii and M. axycephalus at sympatric area was $24.93 \pm 1.95$ and $17.33 \pm 0.72$ respectively, and it seems like the result of character displacement. A finer microhabitat segregation between them is noticed. Yang and Min [14] noted that M. oxycephalus is found along the effluent streams whereas M. lagowskii is distributed mostly in the mainstream at sympatric area.

To clarify the systematics of the fresh-water fishes in Korea, Jeon [15] had drawn up a list and key of the genus Tribolodon, Phoxinus, and Moroco from Korea. For purpose of clarifying their distributional characteristics and distributional districts Jeon [15] had surveyed the micro-distributions of the fishes from March 1988 to February 1989. The distributional characteristics of the Tribolodon hakonensis and T. brandti were influenced by the current of Japan Sea for their anadromous habit and Phoxinus phoxinus from South Korea was confirmed relic distributions. It was confirmed that Korean endemic species is Moroco semotilus and Moroco sp. and M. lagowskii and M. oxycephalus from Kansongbuk-river and Kimhwanamdae-river were sympatrical distributions. The above results are not it accord with the studies of distributional districts of Korean fresh-water fishes by Jeon [15]. Therefore, Jeon [15] suggested that more studies and examinations of the distributional districts of Korean fresh-water fishes should be undertaken.

Surveys of electrophoretic variation in isozymes and general proteins encoded by 26 loci were conducted by Yang and Min [16] to assess species recognition and to estimate the degree of genic variation and species divergence for seven species of the genus Moroco inhabiting in Korea and Japan. Estimates of the average calculated heterozygosity per species of $M$. semotilus, $M$. sp. $M$. percnurus, M. lagowskii, M. oxycephalus, M. steindachneri and $M$. jouyi are low: 0.021, 0.019, 0.051, 0.031, 0.023, 0.046, 0.007, respectively, and observed heterozygosities are $0.038,0.022,0.060$, $0.027,0.025,0.042$, and 0.002 , respectively. Allozyme analyses show these species to be distinct genetically with the latter four species being more closely related one another than any one of them is to the rest of the species. However, these four species (M. lagowskii, M. oxycephalus, M. steindachneri, and M. jouyi), had unique genetic markers in each species to be recognized as valid species. The genetic distances among $M$. semotilus, $M$. sp. and M. percnurus are near the high end of the scale of such estimate for freshwater fish congeners. Based on estimated divergent time of these species of the genus Moroco (5 to 0.6 million years), it is assumed that they are speciated during late Pliocene to middle Pleistocene epoch prior to migration to Korean and Japanese waters through Paleo Amur River system.

The purpose of the study by Min and Yong [17] was to clarify the specific status of Moroco oxycephalus and M. lagowskii by analyzing 883 specimens collected from a sympatric area of these species. Isoryme and morphometric analyses were performed by Min and Yang [17] to identify parental species and possible hybrids. About $12 \%(\mathrm{~N}=104)$ natural hybrids were found. The rate of $\mathrm{F}_{1}$ hybrids was higher $(9 \%)$ than that of $\mathrm{F}_{2}(2.7 \%)$ and decreasing frequency of hybrids according to size class suggests the hybrid inferiority. The scale count (number of scales above lateral line) of $M$. oxycephalus and M. lagowskii were $16.93 \pm 0.92$ and $24.25 \pm 1.32$ respectively and strong character displacement between them was noticed. The scale number of hybrids were intermediate between parental species. Min and Yang [17] pointed out that strong character displacement, fewer hybrids than expected and high mortality rate of hybrids indicate that speciation is completed and premating and postmating isolating mechanisms are both operating.

Park et al. [18] found that Rhynchocypris oxycephalus and $R$. steindachneri show very similar karyotypes: $2 \mathrm{n}=50$ ( $\mathrm{FN}=90)$, consisting of 12 metacentrics, 28 submetacentrics, and 10 acrocentrics with a gradual decrease in chromosome size, but with significant differences in nuclear DNA content of 2.64 and $2.52 \mathrm{pg} /$ nucleus, respectively $(P<0.05)$. Although the erythrocyte measurement and parameters of two species were similar, $R$. oxycephalus erythrocyte number was lower than that of $R$. steindachneri [18]. Park et al. [18] suggested that mode in karyological evolution within the genus Rhynchocypris shows an increase of nuclear DNA without apparent changes in karyotype and erythrocyte size.

The morphological similarity between upstream fatminnow Rhynchocypris oxycephalus and downstream fatminnow Rhynchocypris lagowskii makes it difficult to discriminate accurately between these species in rivers where they coexist [8]. 
For easy and precise identification of these two species, Takai et al. [8] developed a genetic discrimination method based on PCRRFLP analysis for specimens from the Inohzawa River watershed in the Izu Peninsula, central Honshu, Japan. This genetic method was applied to the species identification of the fatminnows from two other watersheds, the Kano and Kawazu Rivers, flowing across the peninsula from north to south. Takai et al. [8] presented the genetic evidence for the restricted distribution of $R$. oxycephalus and the ubiquitous distribution of $R$. lagowskii in the peninsula.

Understanding how populations adapt to different thermal environments is an important issue for biodiversity conservation in the context of recent global warming [19]. To test the hypothesis that populations from southern region are more sensitive to climate change than northern region in cold-water species, Yu et al. [19] determined the thermal tolerance of two geographical populations of a cold-water fish, Rhynchocypris oxycephalus: the Hangzhou population from southern region and the Gaizhou population from northern region, then compared their transcriptomic responses between a control and a high temperature treatment. The results showed that the thermal tolerance range and thermal tolerance polygon area of Hangzhou population were narrower than the Gaizhou population, indicating populations from southern region were possibly more vulnerable. Further transcriptomic analysis revealed that the Gaizhou population expressed more temperature responding genes than the Hangzhou population (583 VS. 484), corresponding with their higher thermal tolerance, while some of these genes (e.g., heat shock protein) showed higher expression in the Hangzhou population under control condition, suggesting individuals from southern region possibly have already responded to the present higher environmental temperature pressure. Therefore, Yu et al. [19] reported that these results confirm the prediction that populations from southern region are more sensitive to global warming and will be important for their future conservation.

Rhynchocypris oxycephalus (Teleostei: Cyprinidae) is a typical small cold water fish, which is distributed widely and mainly in habits in East Asia [20]. Here, Zhang et al. [20] sequenced and determined the complete mitochondrial genome of $R$. oxycephalus and studied its phylogenetic implication. $R$. oxycephalus mitogenome is 16,609 bp in length (GenBank accession no.: MH885043), and it contains 13 protein-coding genes (PCGs), two rRNA genes, 22 tRNA genes, and two noncoding regions (the control region and the putative origin of light-strand replication). 12 PCGs started with ATG, while COl used GTG as the start codon. The secondary structure of tRNA-Ser (AGN) lacks the dihydrouracil (DHU) arm. The control region is $943 \mathrm{bp}$ in length, with a termination-associated sequence, six conserved sequence blocks (CSB-1, CSB-2, CSB-3, CSB-D, CSB-E, CSB-F), and a repetitive sequence. Phylogenetic analysis was performed by Zhang et al. [20] with maximum likelihood and Bayesian methods based on the concatenated nucleotide sequence of 13 PCGs and the complete sequence without control region, and the result revealed that the relationship between $R$. oxycephalus and $R$. percnurus is closest, while the relationship with $R$. kumgangensis is farthest. The genus Rhynchocypris is revealed as a polyphyletic group, and R. kumgangensis had distant relationship with other Rhynchocypris species. In addition, Col and ND2 genes are considered as the fittest DNA barcoding gene in genus Rhynchocypris. This work by Zhang et al. [20] provides additional molecular information for studying $R$. oxycephalus conservation genetics and evolutionary relationships.

Rhynchocypris oxycephalus (Sauvage and Dabry de Thiersant, 1874) distributed in East Asia is small cold-water fish [21]. Park et al. [21] completed whole mitochondrial genome of $R$. oxycephalus caught in Korea. Its length is $16,583 \mathrm{bp}$, which is shorter than those of three mitochondrial genomes from China and Japan. Three hundred ninety seven of 1.278 SNPs and 27 of 44 INDELs are Korean R. oxycephalus specific. It contains 13 protein-coding genes, 2 rRNAs and 22 tRNAs and its GC ratio is $44.5 \%$. Phylogenetic analysis by Park et al. [21] presented genetic diversity of $R$. oxycephalus originated from Korea, Japan, and China.

\section{Rhynchocypris lagowskii:}

Two species of Moroco oxycephalus and M. lagowskii were studied by Min and Yang [13] to examine pattermsof genic variation and morphological differences within and between populations of two species, and to clarify their taxonomic status and geographic distribution. The results obtained from the study of Min and Yang [13] are as this:

a) The number of Scales Above Lateral Line (SAL) was the key character to classify these species. On the average. M. lagowskii had 22 or more SAL whereas M. oxycephalus had 20 or less. Previously known character of the position of dorasal fin was found to be not appropriate to distinguish them

b) Five loci, Gp, Est-1, Est-2, Est-3, and Got-1, showed fixed difference electrophoretically between two species and these could be used as genetic markers to identify them

c) The degree of genic variation of $M$. oxycephalus was for fold higher ( $\bar{H}=0.032$ ) than that of M. lagowskii ( $\bar{H}=0.008$ ) but both species were far less than the average genic variation of freshwater fish in general

d) Roger' genic similarity coefficients between two species were $\bar{S}=0.692$ and their presumed divergent time was estimated to be about 1.8 million years ago.

Detailed survey of the geographic distribution of these species revealed that $M$. lagowskii was distributed in northeastern part of South Korea (Ganseong, Gangreung, Wangsan, and Oggye) and M. oxycephalus was occupied rest of the peninsula. The distance between Oggye, the southern limit of M. lagowskii distribution, and Samwha (near Samcheog), the northern limit of M. oxycephalus, 
was about $15 \mathrm{~km}$ apart and no sympatry was found in between.

The taxonomic status of Moroco lagowskii and M. oxycephalus, a pair of sibling species inhabiting in Korean fresh waters, has been unclear up to date [14]. Recently a sympatric area of these species was found [14]. Yang and Min [14] clarified their specific status by analyzing specimens collected from the sympatric area of these species. Isozyme analysis and morphometric comparison were performed [14]. Among 26 loci screened, 6 loci (Aco, Est-2, E-X, Gp3, Ipo, $M e$ ) showed fixed allelic difference between them and these loci could be used as genetic markers to distinguish them. Isozyme analysis indicates that no hybridization occurs and therefore it is assumed that isolating mechanism is completed and they are distinct species. The mean number of Scales Above Lateral Line (SAL) of $M$. lagowskii and M. axycephalus at sympatric area was $24.93 \pm 1.95$ and $17.33 \pm 0.72$ respectively, and it seems like the result of character displacement. A finer microhabitat segregation between them is noticed. Yong and Min [14] noted that M. oxycephalus is found along the effluent streams whereas M. lagowskii is distributed mostly in the mainstream at sympatric area.

To clarify the systematics of the fresh-water fishes in Korea, Jeon [15] had drawn up a list and key of the genus Tribolodon, Phoxinus, and Moroco from Korea. For purpose of clarifying their distributional characteristics and distributional districts Jeon [15] had surveyed the micro-distributions of the fishes from March 1988 to February 1989. The distributional characteristics of the Tribolodon hakonensis and T. brandti were influenced by the current of Japan Sea for their anadromous habit and Phoxinus phoxinus from South Korea was confirmed relic distributions. It was confirmed that Korean endemic species is Moroco semotilus and Moroco sp. and M. lagowskii and M. oxycephalus from Kansongbuk-river and Kimhwanamdae-river were sympatrical distributions [15]. The above results are not it accord with the studies of distributional districts of Korean fresh-water fishes by Jeon [15]. Therefore, Jeon [15] suggested that more studies and examinations of the distributional districts of Korean fresh-water fishes should be undertaken.

Surveys of electrophoretic variation in isozymes and general proteins encoded by 26 loci were conducted by Yang and Min [16] to assess species recognition and to estimate the degree of genic variation and species divergence for seven species of the genus Moroco inhabiting in Korea and Japan. Estimates of the average calculated heterozygosity per species of $M$. semotilus, $M$. sp $M$. percnurus, M. lagowskii, M. oxycephalus, M. steindachneri, and M. jouyi are low: 0.021, 0.019, 0.051, 0.031, 0.023, 0.046, and 0.007, respectively, and observed heterozygosities are $0.038,0.022,0.060$, $0.027,0.025,0.042$, and 0.002 , respectively. Allozyme analyses show these species to be distinct genetically with the latter four species being more closely related one another than any one of them is to the rest of the species. However, these four species (M. lagowskii, M. oxycephalus, M. steindachneri, and M. jouyi), had unique genetic markers in each species to be recognized as valid species. The genetic distances among M. semotilus, M. sp., and M. percnurus are near the high end of the scale of such estimate for freshwater fish congeners. Based on estimated divergent time of these species of the genus Moroco (5 to 0.6 million years), it is assumed that they are speciated during late Pliocene to middle Pleistocene epoch prior to migration to Korean and Japanese waters through Paleo Amur River system.

The purpose of the study by Min and yong [17] was to clarify the specific status of Moroco oxycephalus and M. lagowskii by analyzing 883 specimens collected from a sympatric area of these species. Isoryme and morphometric analyses were performed by Min and Yang [17] to identify parental species and possible hybrids. About $12 \%(\mathrm{~N}=104)$ natural hybrids were found. The rate of $\mathrm{F}_{1}$ hybrids was higher $(9 \%)$ than that of $\mathrm{F}_{2}(2.7 \%)$ and decreasing frequency of hybrids according to size class suggests the hybrid inferiority. The scale count (number of scales above lateral line) of $M$. oxycephalus and $M$. lagowskii were $16.93 \pm 0.92$ and $24.25 \pm 1.32$ respectively and strong character displacement between them was noticed. The scale number of hybrids were intermediate between parental species. Min and Yang [17] pointed out that strong character displacement, fewer hybrids than expected and high mortality rate of hybrids indicate that speciation is completed and premating and postmating isolating mechanisms are both operating.

Park et al. [18] found that Rhynchocypris oxycephalus and $R$. steindachneri show very similar karyotypes: $2 \mathrm{n}=50$ ( $F N=90)$, consisting of 12 metacentrics, 28 submetacentrics and 10 acrocentrics with a gradual decrease in chromosome size, but with significant differences in nuclear DNA content of 2.64 and $2.52 \mathrm{pg} /$ nucleus, respectively $(P<0.05)$. Although the erythrocyte measurement and parameters of two species were similar, $R$. oxycephalus erythrocyte number was lower than that of $R$. steindachneri [18]. Park et al. [18] suggested that mode in karyological evolution within the genus Rhynchocypris shows an increase of nuclear DNA without apparent changes in karyotype and erythrocyte size.

The morphological similarity between upstream fatminnow Rhynchocypris oxycephalus and downstream fatminnow Rhynchocypris lagowskii makes it difficult to discriminate accurately between these species in rivers where they coexist [8]. For easy and precise identification of these two species, Takai et al. [8] developed a genetic discrimination method based on PCRRFLP analysis for specimens from the Inohzawa River watershed in the Izu Peninsula, central Honshu, Japan. This genetic method was applied to the species identification of the fatminnows from two other watersheds, the Kano and Kawazu Rivers, flowing across the peninsula from north to south. Takai et al. [8] presented the genetic evidence for the restricted distribution of $R$. oxycephalus and the ubiquitous distribution of $R$. lagowskii in the peninsula. 


\section{Reproduction and Development (Refer to Appendix)}

\section{Rhynchocypris oxycephalus}

The early gonadal development and sexual differentiation of Rhynchocypris oxycephalus were described from the stage of hatching to 150 days after hatching by Park et al. [22]. During this period, the average length of the body grew $0.64 \mathrm{~cm}$ to 5.94 $\mathrm{cm}$. The primordial germ cells (PCGs), which could be recognized at the time of hatching, began to protrude into peritoneal cavity at a standard total length of $1.91 \mathrm{~cm}$. At a standard total length of $2.29 \mathrm{~cm}$, initial ovarian differentiation was identified by the transformation of PGCs to meiotic oocytes. Finally, at the standard total length of $5.96 \mathrm{~cm}$, the female gonads gradually developed towards migratory nucleus oocytes, characterizing the maturation. Oocytes proliferated rapidly after sex differentiation while the testis entered a period of quiescence, as they continued to multiply but did not undergo growth until the standard total length of $4.00 \mathrm{~cm}$. At a standard total length of $4.00 \mathrm{~cm}$, spermatocytes arrested in the phase of interkinesis. Sertoli-like cells and sperm duct formation, with signs of meiotic activity, were observed. Therefore, it may be concluded that $R$. oxycephalus belongs to the differentiated type of gonochoristic teleosts.

Kang and Min [23] investigated the reproductive cycles of two freshwater fishes, Moroco oxycephalus and M. lagowskii, in Korea. Seasonal changes in Gonadosomatic Index (GSI) and gonads were investigated histologically from April 1998 to April 1999 [23]. The reproductive cycles of two species were not shown any differences. The reproductive cycle can be divided into 5 phases; phase I (spent phase), phase II (immature phase), phase III (early developing phase), phase IV (late developing phase), and phase V (ripe phase). In phase I, the gonads of two species began to lose distinctly their weights from mid-April and reached the lowest GSI in late July (phase II). In September, the GSI values of testis and ovary increased very slowly (phase III) and gonadal developments rested during the winter season (phase IV). In March, the GSI values of M. oxycephalus and M. lagowskii began to increase and reached the maximum in April (phase V). Kang and Min [23] pointed out that from the cyclic changes in the GSI and histological analyes, the spawning period was between mid-April and mid-May.

The spawning behavior and early life history of Chinese minnow, Rhynchocypris oxycephalus reared in the laboratory were observed by Han et al. [24]. The spawning period of Rhynchocypris oxycephalus is from May to June in nature. The eggs of Rhynchocypris oxycephalus were spawned on the sand and surface of the gravel. The fertilization eggs were demersal in shape and adhesive, released as a clump forming a thin layer and their diameter were 1.70 1.90 $\mathrm{mm}$ (mean $1.80 \mathrm{~mm}, \mathrm{n}=20$ ). Hatching of eggs was started in 88 hours 45 minute after fertilization at water temperature $19 \pm 0.5^{\circ} \mathrm{C}$ and finished in 90 hours. Newly-hatched larvae were measured
4.87 5.02 $\mathrm{mm}$ in total length (TL, mean $4.94 \mathrm{~mm}$ ). Mouth and anus were not opened. 6 days old larvae were $6.32 \sim 6.56 \mathrm{~mm}$ in TL (mean $6.44 \mathrm{~mm}$ ). Yolk sac was almost absorbed, mouth and anus was beginning to open. 13 days old larvae were $6.74 \sim 6.91 \mathrm{~mm}$ in TL (mean $6.82 \mathrm{~mm}$ ). Part of dorsal fin was beginning to rise and myomere number was $15+23=38.25$ days after hatching, total length of larvae was $8.45 \sim 8.60 \mathrm{~mm}$ (mean $8.52 \mathrm{~mm}$ ). Dorsal and anal fin rays became differentiated, and also caudal part of the notochord flexion was achieved at $45^{\circ}$. In the time, growth rate was higher than the other stage. Aggregate numbers of all fin rays were completed at 16.39 16.57 mm in TL (60 days after hatching), at which time the larvae reached the juvenile stage, but fin-fold on ventral was remained yet. External features of adult specimens were almost completed at 80 day old juveniles (18.69 18.87 mm in TL).

The developmental stages of laboratory reared eggs of Rhynchocypris oxycephalus were examined and the external structure during their embryonic period was analysed by Park et al. [25]. Twenty-two embryonic stages of the fish including unfertilized eggs stage at $18^{\circ} \mathrm{C}$ are described with emphasis on the cleavage phases and morphogenesis of external organs and tissues. Adhesive, nonseparatively submersible and greenishyellow colored eggs had a diameter of $1.68 \mathrm{~mm}$ with a yolk of 1.20 $\mathrm{mm}$ in largest and $1.05 \mathrm{~mm}$ in smallest dimension. About $1.5 \mathrm{hrs}$ after fertilization, the blastodisc formed [25]. The first cleavage was completed in $2 \mathrm{hrs}$, the second $2.5 \mathrm{hrs}$, the third $3 \mathrm{hrs}$, the fourth $3.5 \mathrm{hrs}$, the fifth $4 \mathrm{hrs}$, and the sixth $5 \mathrm{hrs}$. They were at morula stage in $8 \mathrm{hrs}$. The gastrulation occurred during the period of 12 14 hrs. Germ ring was apparent and embryonic shield started in 14 16 hrs; embryonic shield became larger and larger and their neural keel was obvious in $20 \mathrm{hrs}$; blastopore closed in 34 40 hrs; 12 myotomes were visible in $52 \mathrm{hrs}$; the number of myotomes increased to 14 16, and the Kupffer's vesicle appeared in $54 \mathrm{hrs}$; auditory vesicle formed in $58 \mathrm{hrs}$; movement of embryo were first observed in 62 hrs; three primary divisions of a brain and two optic lenses were visible, and the melanophore, heart-beating, and twitching movements of the embryo were observed in $64 \mathrm{hrs}$; lower mandible, auditory vesicle, otolith, and 30 myotomes had been differentiated in $71 \mathrm{hrs}$; and the extention on yolk and flow of red blood cells on yolk was observed in 76 hrs. Hatching occurred 78 hrs after fertilization. The newly hatched larvae were an average of $5.0 \mathrm{~mm}$ in total length with ellipsoidal yolk sac, distinct notochords, and myotomes.

To clarify taxonomic status of the two sibling species, Moroco oxycephalus and M. lagowskii reproductive isolation mecahnisms were investigated by Kang et al. [26] at sympatric area located in Kansung-up, Kosung-gun, Kangwon-do, Korea. Genetic analysis was performed to reveal mating system and intensity of hybridization 
between the two species [26]. The frequencies of hybrids were increased since 1989, and then the observed hybrid frequencies (Ho) did not significantly differ from the expected hybrid $\left(\mathrm{H}_{\mathrm{E}}\right)$, in 1998 and 1999. However, based on histological analysis of two parents and their hybrid's gonads, the hybridizations between $M$. oxycephalus and M. lagowskii produced mostly fertile females but sterile males in accordance with Haldane's rule. Althouth it was suspected that pre- and post-mating isolation mechanisms were affected between the two species, M. oxycephalus and M. lagowskii seemed to be strongly isolated with microhabitat at sympatry until 1997. Since 1998, hybrid frequencies were increased by habitat disturbance. However, their hybrid frequencies would be reduced by postmating isolation mechanisms. Therefore, Kang et al. [26] noted that the two species are considered to be distinct species recently diverged.

For the evaluation of hormonal control of spermiation in fish, a method to quantify the spermiation response of mature Rhynchocypris oxycephalus (Sauvage and Dabry) to hormonal therapy is described by Park et al. [27]. Spermatocrit was determined after $7 \mathrm{~min}$ centrifrigation at 18,000 $\times \mathrm{g}$ and sperm density was estimated by a standard hemocytomer method. Sperm density can be predicted from spermatocrit since their relationship is linear as described by the regression equation, $\mathrm{Y}=3.68 \mathrm{X}-27.18$ $\left(R^{2}=0.82, \mathrm{~N}=50\right)$. Where $\mathrm{Y}$ is spermatocrit and $\mathrm{X}$ is sperm density. Milt production by mature $R$. oxycephalus was highest at $24 \mathrm{~h}$ after injection of 1,000 IU Human Chorionic Gonadotropin (HCG) and 50 ug Luteinizing Hormone-Releasing Hormone Analogue (LHRHa) per kg body weight. Increased milt production coincided with low spermatocrit and sperm density levels. These results by Park et al. [27] demonstrated that spermiation in mature $R$. oxycephalus can be reliably evaluated by a spermatocrit method and that HCG and LHRHa are effective in stimulating of spermiation in this species.

The effectiveness of Human Chorionic Gonadotropin (HCG), a super active analogue of mammalian luteinizing Hormone Releasing Hormone (LHRHa) and Carp Pituitary (CP) for inducing ovulation in Rhynchocypris oxycephalus (Sauvage and Dabry) was examined and the effects of the maternal hormone treatment on egg quality were evaluated by Park [28]. None of the control group and sham (saline injected) control group ovulated [28]. The majority (76 96\%) of the hormone treated groups ovulated within 2 days after hormone injection. Studies of egg quality, e.g., fertilization rate, and hatching demonstrated that good quality $R$. oxycephalus (Sauvage and Dabry) offspring can be produced after accelerated spawning by HCG, LHRHa, and CP. The increase in egg diameter and number of eggs spawned may have been caused by the increase in the body weight of the females.

Oocyte surface in two Korean minnows, Rhynchocypris oxycephalus and R. kumgangensis was examined by light and electron microscope [29]. In two species, the development of the oocyte was similar, but the follicular layer surrounding fullgrown oocyte showed an evident difference. In R. oxycephalus, the follicular layer at the yolk vesicle stage became bilaminar with the retention of its outer squamous cell layer and the acquisition of an inner cuboidal or round cell layer just over the zona radiate. As the oocyte grows, the cuboidal cells of the inner follicular layer began to be replaced by columnar cells. At the yolk granule stage, the columnar cells secreted mucin to their cytoplasm (adhesive materials) and then surround the entire oocyte, as bundles of fence-shaped structures. Whereas, although the follicular layer of $R$. kumgangensis had an outer squamous layer and an inner cuboidal or round cell layer at the yolk vesicles as in R. oxycephalus, no inner cells were more changed with the retention of its cuboidal or round cells. Finally, in R. kumgangenesis, the adhesive materials did not ocuur. Gwak and Park [29] suggested that in Korean two minnows, the structural difference in the oocyte surface seems to be related to their habitats and spawning characteristics as well as taxonomic characters.

\section{Rhynchocypris lagowskill:}

Chinese minnow, Rhynchocypris oxycephalus is a teleost belonging to Leuciscinae, Cyprinidae [30]. The oogenesis and ultrastructure of egg envelope in Chinese minnow were investigated by light and electron microscopes by Kim et al. [30]. The ovary was of white yellowish and ellipsoidal shape with the major axis 30 $\mathrm{mm}$ and the minor axis $7 \mathrm{~mm}$. Cytoplasm of oogonia was basophilic and many nucleoli were located at inside of nuclear membrane. In primary oocytes, yolk vesicles were distributed only in the marginal area and egg envelope was not formed on the outside of an egg. In secondary oocytes, the egg envelope was formed and yolk vesicles in the cytoplasm were increased than the earlier stage. The basophilic substance of cytoplasm was changed to acidic. In case of matured egg, thickness of egg envelope and size of egg were increased. The yolk vesicles were changed to yolk mass in accordance with development. The outer surface of egg envelope was covered by microvilli-structures and had a micropyle on the area of animal pole. Egg envelope consisted with 2 layers, an adhesive outer layer with microvilli-structures and fibrillary inner layer. Kim et al. [30] concluded that the oogenesis of Chinese minnow was characterized by the increase in cell size, the formation and accumulation of yolk, and the decrease of basophilic substance in the cytoplasm. The oogenesis of Chinese minnow seems to share common patterns in Cyprinidae, but these ultrastructural unique characters of egg envelope can be utilized in taxonomy of teleost.

The ultrastructure of spermatogenesis and sperm in Chinese minnow, Rhynchocypris oxycephalus belonging to Leuciscinae was investigated with light and electron microscopes by Kim et al. [31]. The whitish testis was located between intestine and air bladder. 
The size of testis was major axis $2.3 \mathrm{~cm}$, minor axis $6 \mathrm{~mm}$. The testis contained numerous testicular cysts, and spermatogenesis was non-synchronized in these testicular cysts. In the case of spermatogonium, the nucleus was comparatively large ellipsoidal, and mitochondria showed a marked development. The size of primary spermatocyte was smaller than that of spermatogonia, and secondary spermatocyte was smaller than primary spermatocyte. The chromatin of spermatocyte was highly condensed according to their development. The nucleus with electron-dense was round shape [31]. In spermiogenesis, flagella started to be formed and chromatin was more condensed. The mitochondria were rearranged in middle piece. The sperm was formed by loss of cytoplasm. The head of mature sperm was a spherical shape and have not acrosome. The microtubules of flagella were arranged 9+2 structure. Also, the tail of sperm have not lateral fins.

\section{Ecology (Refer to Appendix)}

\section{Rhynchocypris oxycephalus:}

A series of assessments on the biological control potential with the common fat minnow (Moroco oxycephalus) and oriental weatherfish (Misgurnus anguillicaudatus) were conducted against Culex pipiens pallens, Culex tritaeniorhynchus, and Anopheles sinensis larvae both in the laboratory and semifield rice paddies of University Experimental Station in Suwon from July through September, 19921993 by Kim et al. [32]. In the laboratory, the higher predation rate by one mature fish (M. oxycephalus) against C. pipiens pallens larvae was on the average of 210.5 larvae per day, followed by $A$. sinensis and C. tritaeniorhynchus as 167.9 and 160.0, respectively. A mature fish of $M$. anguillicaudatus consumed $C$. pipiens on the average of 168.4 third instar larvae per day; an immature fish consumed in range of 112.7-144.0 larvae per day. Predation of the fish at 3 different release rates of 1,2 , and 4 fish per aquarium resulted in 129.5 , 253.8, and 320.6 3rd-instar mosquito larvae, respectively. In semi-field assessment, $M$. oxycephalus at the release rates of 1, 2, 4, and 8 fish per $\mathrm{m}^{2}$ resulted in $43.6 \%, 50.4 \%, 63.6 \%$, and $71.8 \% \mathrm{~A}$. sinensis control after 1 week respectively; subsequent, biocontrol rate increased to $100.0 \%$ in higher release rate groups ( $4 \mathrm{fish} / \mathrm{m}^{2}$, $8 \mathrm{fish} / \mathrm{m}^{2}$ ), however, in a substantial control of $71.6 \%$ was obtained from 2 fish per $\mathrm{m}^{2}$ in 3 weeks after the fish introduction. Misgurnus anguillicaudatus introduction at $2 \mathrm{fish} / \mathrm{m} 2$ produced $34.6 \%$ and $35.3 \%$ A. sinensis reduction in ca. 4 and 8 weeks respectively; while 4 fish per $\mathrm{m}^{2}$ yielded substantial biological control against A. sinensis, C. pipiens pallens, and C. tritaeniorhynchus combined, by $53.8 \%$ and $55.2 \%$ in ca. 4 and 8 weeks in comparision with that of control paddies.

Global climate change has been suggested to cause decrease of distribution area of many species [33]. However, this has not been tested for East Asian inland coldwater fish [33]. Chinese minnow (Rhynchocypris oxycephalus) is a small typical coldwater fish, which is endemic to East Asia and generally inhabits stream headwaters [33]. Due to its occurrence in temperate south China, there is growing concern about its future fate in the face of global warnming [33]. In this study, Yu et al. [33] employed maximum entropy approach to analyze how distribution of this species would be impacted by future climate change. Yu et al. [33] collected data of 310 independent distribution points and 20 environmental variables and conducted modelling under three general circulation models assuming two gas emission scenarios for 2020s, 2050s, and 2080s. The result obtained from study of Yu et al.[33], showed that the Min temperature of coldest month was the most important climatic variable for potential distribution of Chinese minnow. Modeling predicted geographical distribution of the Chinese minnow would shrink over time and become much more limited in all the situations especially in South-eastern China, and there would be little uitable habitat left in this region by 2080s. The results of Yu et al. [33] confirm that climate change clearly poses a severe threat to the Chinese minnow, and Yu et al. [33] suggested that conservation efforts should focus on lower temperature areas within the current range, because these areas will remain relatively cool and may be still suitable for the Chinese minnow even under the most drastic climate change scenarios.

The study of Yu et al. [11] demonstrated that geological events (three steps orogenesis) and climate fluctuations during the Pliocene were important factors in shaping phylogeographical patterns in Rhynchocypris oxcephalus. Notably, no genetic diversity was detected in several populations, all of which possessed unique genotypes. This indicates the uniqueness of local populations and calls for a special conservation plan for the whole species at the population level.

Rhynchocypris oxcephalus is a short-lived, fast-growing, highly fecund, and early-maturing species; therefore, even a short recovery time after overexploitation or disturbance would be of great use for their restoration. Liang et al. [9] pointed out that some life history traits of R. oxycephalus demonstrate obvious differences with its closely related species, indicating that latitude and local environment conditions are important selective forces for this species.

In Japan, domestic freshwater fish are accidentally introduced into non-native freshwater habitats by human activity, such as the planting of fish [34]. Introduction of the domestic alien fish may have a detrimental effect on native fish inhabitants [34]. However, investigations on the distribution and establishment of such domestic alien fish in non-native river basins and their influence on native fish remains limited [34]. Therefore, Nishida et al. [34] investigated the distribution and establishment of the domestic 
alien fish Rhynchocypris oxycephalus and its influence on native fish in the Tama River Basin, Japan. Specifically, Nishida et al. [34] used mitochodrial DNA and morphological analyses to clarify the influence of the invasion of this species on the distribution of the closely related fish $R$. lagowskii, which is native to the river basin. Fish sampled from the upstream section of the main river were mostly $R$. oxycephalus. This indicates that $R$. oxycephalus has replaced $R$. lagowskii in the upstream region. Fish sampled from the downstream section of the main river were mostly $R$. lagowskii. $R$. oxycephalus was also captured from agricultural canals linked to the Tama River, and in streams connected to the river via the canals. These observations by Nishida et al. [34] indicated that the agricultural canal water metworks facilitate the invasion of $R$. oxycephalus to peripheral habits, such as canals and streams. In contrast, $R$. lagowskii was found in streams that flowed into the upstream section of the Tama River, with these streams having many large drop structures, indicating that drop structures prevent R. oxycephalus from invading aquatic habitats in these streams.

The study was performed by Lee et al. [35] to evaluate the newly-developed Juvenile Fish Shelter (JFS) for its ability to increase prey survival and to improve species diversity in a freshwater ecosystem. An experiment was performed in an outdoor large-scale mesocosm three times from 2011 to 2012 by comparing the responses to adjustment as a function of the volume of JFS in the control and experimental groups. Analysis results of the environmental monitoring over three periods indicated only minor differences in the physicochemical characteristics of the water quality and phyto- and zoo-plankton biomass, thereby enabling a comparative analysis of the feeding ecology. However, the water temperature exhibited large fluctuations, ranging from $16.4^{\circ} \mathrm{C}$ to $27.6^{\circ} \mathrm{C}$, and high water temperature conditions (Period $1,25.6 \pm 2.0^{\circ} \mathrm{C}$ ) enhanced the predation activity of the piscivorous fish Coreoperca herzi (C. herzi, size $89 \pm 4 \mathrm{~mm}$ ). Statistically, the survuval rates of the prey fish, Rhynchocypris oxynchocypris $(R$. oxycephalus, size $29 \pm 1 \mathrm{~mm}$ ), wish JFSs were greater by $35.9 \%$ $46.7 \%$, and improved as the patch volume of JFS increased. Based on both experimental observations and statistical analysis by Lee et al. [35], the JFS developed in this study could reduce the chances of predator-prey encounters, minimize prey vulnerability, and thereby increase prey survival rates.

The feeding habits of the Chinese minnow, Rhynchocypris oxynchocypris (Sauvage \& Dabry de Thiersant, 1874), were investigated in the Laohegou River, a tributary of the upper Yangtze River, China by Lei et al. [36]. A total of 412 specimens were collected by electrofishing in four seasons of 2012, 7 days per season. Diet composition was analyzed according to season, size classes and sex. The Chinese minnow is a generalist omnivorous species, whose diet consists of aquatic insects and plants. Besides algae, Hemiptera, Ephemerida, Trichoptera, Odonata, Diptera were the most dominate food items. The Shannon-Wiener index on diet items showed no significant differences between major food items $(P<0.05)$ or between seasons, size classes and sexes. In contrast, fullness index and dietary breadth analysis both indicated significant diet changes between seasons. Consequently, this study performed by Lei et al. [36] provides information on feeding habits of $R$. oxynchocypris, which may be useful in cultivation trials.

\section{Rhynchocypris lagowskii:}

In Japan, domestic freshwater fish are accidentally introduced into non-native freshwater habitats by human activity, such as the planting of fish [34]. Introduction of the domestic alien fish may have a detrimental effect on native fish inhabitants [34]. However, investigations on the distribution and establishment of such domestic alien fish in non-native river basins and their influence on native fish remains limited [34]. Therefore, Nishida et al. [34] investigated the distribution and establishment of the domestic alien fish Rhynchocypris oxycephalus and its influence on native fish in the Tama River Basin, Japan. Specifically, Nishida et al. [34] used mitochodrial DNA and morphological analyses to clarify the influence of the invasion of this species on the distribution of the closely related fish $R$. lagowskii, which is native to the river basin. Fish sampled from the upstream section of the main river were mostly $R$. oxycephalus. This indicates that $R$. oxycephalus has replaced $R$. lagowskii in the upstream region. Fish sampled from the downstream section of the main river were mostly $R$. lagowskii. $R$. oxycephalus was also captured from agricultural canals linked to the Tama River, and in streams connected to the river via the canals. These observations by Nishida et al. [34] indicated that the agricultural canal water metworks facilitate the invasion of $R$. oxycephalus to peripheral habits, such as canals and streams. In contrast, R. lagowskii was found in streams that flowed into the upstream section of the Tama River, with these streams having many large drop structures, indicating that drop structures prevent $R$. oxycephalus from invading aquatic habitats in these streams.

\section{Starvation (Refer to Appendix)}

\section{Rhynchocypris oxycephalus}

The influence of nutritional conditions on the histological changes of hepatocyte and intestinal epithelium as well as Hepatosmatic Index (HSI), protein, RNA, and DNA concentrations of liver of Rhynchocypris oxycephalus was tested by Lee et al. [37]. Although, the starved group showed higher concentrations of protein, DNA, and RNA than the fed group, food deprivation resulted in a decrease in the HIS, hepatocyte nucleus size and nuclear height of the intestinal epithelium. The RNA-DNA ratio appears to be a useful index of nutritional status in $R$. oxycephalus and may be useful for determining if $R$. oxycephalus is in a period of 
rapid or slow growth at the time of sampling. Additionally, the data have been interpreted in detail and some biologically important relationships discussed by Lee et al. [37].

The effects of starvation on the morphometrical changes in sectioned body traits, condition factor, viscera index, and dressing percentage were determined for evaluating nutritional conditions of Rhynchocypris oxycephalus (Sauvage and Dabry) by Park et al. [38]. Starvation for nine weeks resulted in a decrease in most sectioned traits as well as in condition factor and viscera index $(P<0.05)$. These findings suggest that nutritional parameters used in this study appear to be a useful index for nutritional status in this species. The data has been interpreted in detail and some important body sectioned values of interest to commercial growers discussed by Park et al. [38].

A 75-day study was conducted to determine the effect of starvation on classical and truss parameters in Rhynchocypris oxycephalus (Sauvage and Dabry) by Park et al. [4]. Truss dimensions of almost the entire head and trunk region as well as the abdomen were increased significantly through feeding or starvation $(p<$ 0.05). Truss dimensions of the caudal region generally decreased through feeding or starvation, particularly those dimensions at the hind part of the trunk. There were some significant decreases in classical dimension of the head region during feeding, in relation to body depth characteristics in the trunk and caudal region during starvation, whereas there was only one decreasing classical dimension in the caudal region during feeding. The results of this study indicate that application of the truss network as a character set enforces classical coverage across the body form, discrimination among experimental groups thus being enhanced. Considering that the dimension of the lower part of the head and some truss and classical dimensions were least affected by feeding and starvation, these dimensions may then be useful as a taxonomical indicator to discriminate the species of Rhynchocypris sp. Park et al. [4] suggested that the value of trunk region dimensions with a large component of body depth in $R$. oxycephalus is most likely to be compromised by variability related to differences in feeding regimes of fish in different habitats.

Following the previous experiments, a starvation experiment was conducted to determine the influence of feeding and starvation on the histological and biochemical changes, the morphormetric changes in the sectioned body and the morphometric changes in Rhynchocypris oxycephalus (Sauvage and Dabry) [39]. The influence of starvation on nutritional conditions of the histological changes of hepatocyte and intestinal epithelium as hepatosmatic Index (HSI), protein, $R N A$, and DNA concentrations of liver in $R$. oxycephalus was tested by Park [39]. Although the starved group showed higher concentrations of protein, DNA, and RNA than the fed group, food deprivation resulted in a decrease in the HSI, hepatocyte nucleus size, and nuclear height of the intestinal epithelium. The RNA-DNA ratio appears to be a useful index of nutritional status in $R$. oxycephalus and may be useful for determining if $R$. oxycephalus is in a period of rapid or slow growth at the time of sampling. Additionally, the data have been interpreted in detail and some biologically important relationships discussed by Park [39]. The effects of starvation on the morphometrical changes in sectioned body traits, condition factor, viscera index, and dressing percentage were determined for evaluating nutritional conditions of $R$. oxycephalus by Park [39]. Starvation for nine weeks resulted in a decrease in most sectioned traits as well as in condition factor and viscera index $(P<0.05)$. These findings suggest that nutritional parameters used in this study appear to be a useful index for nutritional status in this species. The data has been interpreted in detail and some important body sectioned values of interest to commercial growers discussed. A 75-day study was conducted to determine the effect of starvation on classical and truss parameters in $R$. oxycephalus by Park [39]. Truss dimensions of almost the entire head and trunk region as well as the abdomen were increased significantly through feeding or starvation $(P<0.05)$. Truss dimensions of the caudal region generally decreased through feeding or starvation, particularly those dimensions at the hind part of the trunk. There were some significant decreases in classical dimensions of the head region during feeding, in relation to body depth characteristics in the trunk and caudal region during starvation, whereas there was only one decreasing classical dimension in the caudal region during feeding. The results of this study indicate that application of the truss network as a character set enforces classical coverage across the body form, discrimination among experimental groups thus being enhanced. Considering that the dimension of the lower part of the head and some truss and classical dimensions were least affected by feeding and starvation, these dimensions may then be useful as a taxonomical indicator to discriminate the species of Rhynchocypris sp. Park [39] suggested that the value of trunk region dimensions with a large component of body depth in $R$. oxycephalus is most likely to be compromised by variability related to differences in feeding regimes of fish in different habitats.

\section{Environmental biology (Refer to Appendix)}

\section{Rhynchocypris oxycephalus}

Deformed vertebrae by cold shock in Rhynchocypris oxycephalus were discovered by Park [40]. Deformity was externally noticed in the caudal penducle region of $R$. oxycephalus. Radiographic and histologic investigation confirmed the deformity. Especially, histological investigations provided the fact that extensive fusion between neighbouring vertebrae is caused by removal of endogeneous mineralized tissue. Deformed vertebrae appeared suggesting the direct evidence of vertebral fusion had arisen internally by cold shock in this species. 
Twelve-week feeding trial was performed to investigate effectiveness of dietary thyroxine and iodide on growth of Rhynchocypris oxycephalus (Sauvage and Dabry) by Park et al. [41]. One hundred and twenty-day old larvae $(4.48 \mathrm{~cm}$ in mean total length and $0.84 \mathrm{~g}$ in mean wet body weight) were used as the experimental fish and acclimated into the experimental conditions. Two levels of concentrations ( 1 and $5 \mathrm{ppm}$ ) of sodium-L-thyroxine $\left(\mathrm{T}_{4}\right)$ and three levels of concentrations (15 and $25 \mathrm{ppm}$ ) sodium iodide (I) were sprayed on commercial feed for carp. Commercial feed for carp without spraying $\mathrm{T}_{4}$ or I was used as control. Fish were fed to visual satiety for 12 weeks. Water quality was regularly monitored throughout the feeding trial. The control group showed 97.5\% survival. Fish in the experimental groups at the end of the feeding trial achieved similar survival to control group and their appearance was to be normal without any deformity in all treatments. Weight gain (\%) and specific growth rate of fish fed the diet with $\mathrm{T}_{4}$ at $1 \mathrm{ppm}$, in order. Daily feed intake of fish fed on the diet with $\mathrm{T}_{4}$ at $5 \mathrm{ppm}$ and I at $1 \mathrm{ppm}$ were significantly $(P<0.05)$ higher than that of fish fed on the other diets. Daily feed intake of fish fed on the diet with I at 25 ppm was highest. Feed efficiency ratio for fish fed on the diet with I at $25 \mathrm{ppm}$ was highest followed by me at $5 \mathrm{ppm}, \mathrm{T}_{4}$ at $1 \mathrm{ppm}$, control, I at $1 \mathrm{ppm}$ and $\mathrm{T}_{4}$ at $5 \mathrm{ppm}$ in order. This indicated that high weight gain and specific growth rate for fish fed the diet with $\mathrm{T}_{4}$ at $5 \mathrm{ppm}$ resulted from high daily feed intake, and eventually led to low feed efficiency ratio. Condition factor of fish fed the diet with I at $1 \mathrm{ppm}$ was significantly $(P<0.05)$ higher than that of fish fed the other diets. The results obtained from the study of Park et al. [41] indicated that $5 \mathrm{ppm} \mathrm{T}_{4}$ and $1 \mathrm{ppm}$ I treatment were effective for growth promotion in $R$. oxycephalus.

Vitellogenin (Vtg), a phospholipoglycoprotein precursor of egg yolk is synthesized and secreted from the liver in response to estrogens in female fish [42]. Vtg is normally undetectable in the blood of male fish but can be induced by exposure to chemicals possessing estrogenic activity [42]. Thus, the presence of Vtg in blood of male fish can serve as a useful biomarker for assessing previous exposure to estrogenic compounds [42]. In the study of shin et al. [42], Vtg was abnormally expressed in Rhynchocypris oxycephalus using estradiol benzoate $\left(\mathrm{E}_{2}\right)$. As the result, it was found that the level of Vtg in blood from $R$. oxycephalus was increased by treated quantity of $E_{2}$ with dose-effect manner. Monoclonal antibodies were generated against Vtg of $R$. oxycephalus. The hybridoma were screened with an enzyme immunoassay for the production of specific anti-Vtg antibodies by Shin et al. [42]. Five positive cell lines with a high specificity were selected. Monoclonal antibodies against Vtg of $R$. oxycephalus that was developed in the study of Shin et al. [42], may be a useful bio-indicator for the detection of estrogenic contamination in the aquatic ecosystem.

An experiment measuring the concentration ratios of ${ }^{137} \mathrm{Cs}$ and ${ }^{85} \mathrm{Sr}$ in fish as an index aquatic animal was performend by Jun et al. [43]. The species was Chinese minnow (Rhynchocypris oxycephalus), a Korean native freshwater species. Chinese minnows were reared in acryl aquarium which was $45 \mathrm{~cm}$ wide, $85 \mathrm{~cm}$ long, and $50 \mathrm{~cm}$ high. Water in the aquarium was successively purified using filtering devices attached on the floor and the well. Fish powder in a particulate form was supplied twice a day for feeding. After a radioactive solution was added to make the initial water concentrations approximately $0.02 \mu \mathrm{Ci} / \mathrm{l}$ and $0.1 \mu \mathrm{Ci} / \mathrm{l}$ for ${ }^{137} \mathrm{Cs}$ and ${ }^{85} \mathrm{Sr}$, respectively, the fish and water were sampled 10 times for a month. The study of Jun et al. [43] pointed out that the connectration ratios were measured to $0.348 \mathrm{lkg}^{-1} \sim 13.906 \mathrm{lkg}^{-1}$ for ${ }^{137} \mathrm{Cs}$ and $0.474 \mathrm{lkg}^{-1} \sim 13.089 \mathrm{lkg}^{-1}$ for ${ }^{85} \mathrm{Sr}$

\section{Techniques (Refer to Appendix)}

\section{Rhynchocypris Oxycephalus:}

The effectiveness of lidocaine $\mathrm{HCI}$ (lidocaine $\mathrm{HCl}$ /sodium bicarbonate mixture) was tested as an anaesthetic for Rhynchocypris oxycephalus and $R$. steindachneri at three different temperatures of $10^{\circ} \mathrm{C}, 15^{\circ} \mathrm{C}$, and $20^{\circ} \mathrm{C}$ by Park et al. [44]. Based on the exposure and recovery time, effective doses of lidocaine $\mathrm{HCI}$ were proven to be $300 \mathrm{ppm}\left(20^{\circ} \mathrm{C}\right), 400 \mathrm{ppm}\left(15^{\circ} \mathrm{C}\right)$, and $600 \mathrm{ppm}\left(10^{\circ} \mathrm{C}\right)$ for $R$. oxycephalus, and $400 \mathrm{ppm}\left(20^{\circ} \mathrm{C}\right), 500 \mathrm{ppm}\left(15^{\circ} \mathrm{C}\right)$, and $600 \mathrm{ppm}$ $\left(10^{\circ} \mathrm{C}\right)$ for $R$. steindachneri, respectively. Anaesthetic dose and temperature-dependent relationship in exposure and recovery time were observed for these two Rhynchocypris spps. There were size-related increases of exposure time on $R$. steindachneri in each dose of lidocaine HCI [44]. However, dose-dependent increase of recovery time was found in only the large size group of Rhynchocypris spp.

Rhynchocypris oxycephalus was incised through the midlateral line between the dorsal and pectoral fins and the wounds were closed with absorbable synthetic suture, and here Park et al. [45] describe histological details on the nature of second-intention wound healing, rate of healing, and the nature of granulation tissue contraction. Postoperative survivals were $95 \%$ and $99 \%$, compared to $100 \%$ for counterpart control fish, among fish at just and 7 days after surgery, respectively. By 14 42 days after surgery, fish had no mortality. The granulation tissue was epithelialized from day 7 through day 22 postsurgery. By 28 days postsurgery, the granulation tissue had contracted the wound margins into apposition. By 35 42 days postsurgery, the granulation tissue contained collagen fiber and the epidermis contained well-differentiated alarm substance cells; thus, the epidermis over the wound site was histologically normal in most fish, showed that wound healing was essentially complete within 35 days of surgery.

The experimental transportation of Rhynchocypris steindachneri was carried out to study the effects of lidocaine-hydrochloride on water parameters by Park et al. [46]. The dissolved oxygen, ventilation rate, ammonia nitrogen, and $\mathrm{pH}$ of control group, sham control group, and lidocaine-hydrochloride treated groups of $2.5 \mathrm{ppm}, 5 \mathrm{ppm}, 10 \mathrm{ppm}$, and $20 \mathrm{ppm}$ at time of $30 \mathrm{~min}, 60 \mathrm{~min}, 90$ 
min, $120 \mathrm{~min}, 240 \mathrm{~min}$, and $360 \mathrm{~min}$ after elapsed from treatment were tested. During the experiment time it was found that lidocaine-hydrochloride treated groups were most effective, followed by sham control and control, in decreasing the oxygen consumption and the excretion of ammonia by the fish. There were lidocaine-hydrochloride dose-related decrease in oxygen consumption and the excretion of ammonia. Decreasing in $\mathrm{pH}$ value of lidocaine-hydrochloride groups and sham control group was much higher than that of control group. The results obtained from the study of Park et al. [46] revealed lidocaine-hydrochloride is effective as sedative for transportation mixture in $R$. steindachneri.

\section{Rhynchocypris lagowskii:}

The effectiveness of lidocaine $\mathrm{HCl}$ (lidocaine $\mathrm{HCl}$ /sodium bicarbonate mixture) was tested as an anaesthedtic for Rhynchocypris oxcephalus and $R$. steindachneri at three different temperatures of $10^{\circ} \mathrm{C}, 15^{\circ} \mathrm{C}$, and $20^{\circ} \mathrm{C}$ by Park et al. [44]. Based on the exposure and recovery time, effective doses of lidocaine $\mathrm{HCl}$ were proven to be $300 \mathrm{ppm}\left(20^{\circ} \mathrm{C}\right), 400 \mathrm{ppm}\left(15^{\circ} \mathrm{C}\right)$, and $600 \mathrm{ppm}$ $\left(10^{\circ} \mathrm{C}\right)$ for R. oxcephalus, and $400 \mathrm{ppm}\left(20^{\circ} \mathrm{C}\right), 500 \mathrm{ppm}\left(15^{\circ} \mathrm{C}\right)$, and $600 \mathrm{ppm}\left(10^{\circ} \mathrm{C}\right)$ for $R$. steindachneri, respectively. Anaesthetic dose and temperature-dependent relationship in exposure and recovery time were observed for these two Rhynchocypris spp. There were size-related increases of exposure time on R. steindachneri in cach dose of lidocaine $\mathrm{HCl}$. However, dose-dependent increase of recovery time was found in only the large size group of Rhynchocypris spp.

The experimental transportation of Rhynchocypris steindachneri was carried out to study the effects of lidocaine-hydrochloride on water parameters by Park et al. [46]. The dissolved oxygen, ventilation rate, ammonia nitrogen, and $\mathrm{pH}$ of control group, sham control group, and lidocaine-hydrochloride treated groups of 2.5 ppm, $5 \mathrm{ppm}, 10 \mathrm{ppm}$, and $20 \mathrm{ppm}$ at time of $30 \mathrm{~min}, 60 \mathrm{~min}, 90 \mathrm{~min}$, $120 \mathrm{~min}, 240 \mathrm{~min}$, and $360 \mathrm{~min}$ after elapsed from treatment were tested. During the experiment time it was found that lidocainehydrochloride treated groups were most effective, followed by sham control and control, in decreasing the oxygen consumption and the excretion of ammonia by the fish. There were lidocainehydrochloride dose-related decrease in oxygen consumption and the excretion of ammonia. Decreasing in $\mathrm{pH}$ value of lidocainehydrochloride groups and sham control group was much higher than that of control group. The results obtained from the study of Park et al. [46] revealed lidocaine-hydrochloride is effective as sedative for transportation mixture in $R$. steindachneri.

\section{Conclusion}

Two species of Rhynchocypris oxycephalus and R. lagowskii which are an Asian species of small freshwater cyprinid fish. In this paper, I provides information on a review of studies concerning a wide category of zootaxy, reproduction \& development, ecology, starvation, environmental biology, and techniques for Rhynchocypris oxycephalus and $R$. lagowskii, which were done over a perid of 21 years from 1998 to 2019 in order to highlight the recent progress in different fields of study using these species.

\section{Competing Interests}

The author declares no competing interests.

\section{Funding}

This review recerved no external funding.

\section{Author's contribution}

The author read and approved the final manusetript.

\section{Acknowledgements}

The author wish to thank the anonymous referees for the constructive and helpful comments on the revision of this article. I am thankful the staff of the Fishery Genetics and Breeding Sciences Laboratory of the Korea Maritime \& Ocean University (KMOU), Republic of Korea helping me write this paper. This study complied with guidelines for Securing the Research Ethics of the Ministry of Education (Article 15 of the Acadermic Promotion Act) and the Standards of the Act on Laboratory Animals of the Ministry of Food and Drug Safety (Law No. 1601), as well as the Research Ethics of KMOU, Republic of Korea.

\section{References}

1. Froese, Rainer, Pauly, Daniel (2014) "Rhynchocypris oxycephalus" and "Rhynchocypris lagowskii" in FishBase.

2. Kim IS, Park JY (2002) Fish of Korea. In Kim IS, Park JY (Eds.), KyoHak Publishing, Korea.

3. Chen Y (1998) Fauna Sinica, Osteichthyes, Cypriniformes. In Chen Y (Ed.), Science Press, Beijing. pp. 75-88.

4. Park IS, Im JH, Ryu DK, Nam YK, Kim DS (2001) Effect of starvation on marphametric changes in Rhynchocypris oxycephalus (Sauvage and Dabry). Journal of Applied Ichthyology 17(6): 277-281.

5. Ito Y, Sakai H, Shedko S, Jeon SR (2002) Genetic differentiation of the northern Far East cyprinids, Phoxinus and Rhynchocypris. Fishery Science 68(Suppl 1): 75-78.

6. Sakai H, Ito Y, Shedko SV, Safronov SN, Frolov SV (2006) Phylogenetic and taxonomic relationships of northern Far Fastern phoxinin minnows, Phoxinus and Rhynchocypris (Pisces, Cyprinidae), as inferred from allozyme and mitochondrial 16S tRNA sequence analyses. Zoological Science 23(4): 232-331.

7. Bogutskaya NG, Naseka AM, Shedko SV, Vasileva ED, Chereshnev IA (2008) The fishes of the Amur River: updated check-list and zoogeography. Ichthyol Explor Fres 19(4): 301-366.

8. Takai N, Abiko Y, Tsukamoto H, Miura A, Yuasa K (2012) Species indentification of upstream fatminnow Rhynchocypris oxycephalus and downstream fatminnow Rhynchocypris lagowskii, based on PCR-RFLP of mitochondrial DNA. Ichthyological Research 59: 156-163.

9. Liang Y, Sui X, Chen Y, Jia Y, He D (2014) Life history traits of the Chinese minnow Rhynchocypris oxycephalus in the upper branch of Yangtz river. China Zoological Studies 53: 36

10. Jang MH, Kim JG, Park SB, Jeong KS, Cho G (2002) The current status of the distribution of introduced fish in large river systems of South Korea. International Review of Hydrobiology 87(2-3): 319-328. 
11. Yu D, Chen M, Tang Q Li X, Liu H (2014) Geological events and pliocene climate fluctuations explain the phylogeographical pattern of the cold water fish Rhynchocypris oxycephalus (Cypriniformes: Cyprinidae) in China. BMC Evolutionary Biology 14(1): 225.

\section{WikipediA. c2001 (2001) Amur minnow.}

13. Min MS, Yang SY (1986) Classification, distribution and geographic variation of two species of the genus Moroco in Korea. Korean Journal of Systematic Zoology 2: 63-78.

14. Yang SY, Min MS (1988) Sympatry and species status of Moroco lagowski and M. oxycephalus (Cyprinidae). Korean Journal of Zoology 31(1): 56$-61$.

15. Jeon SR (1989) Studies on the key and distribution of the genus Tribolodon, Phoxinus and Moroco (Pisces: Leuciscinae) from Korea. Journal of Basic Sciences, Sang Myung Woman's University 3: 17-36.

16. Yang SY, Min MS (1989) Genetic variation and speciation of fishes of genus Moroco (Cyprinidae). Korean Journal of Zoology 32(2): 75-83.

17. Min MS, Yang SY (1992) A study on the natural hybridizaion between Moroco lagowskii and M. oxycephalus. Korean Journal of Zoology 35: 339-343.

18. Park IS, Choi Y, Kim YH, Nam YK, Kim DS (2000) Flow cytometric and cytogenetic studies in Rhynchocypris oxycephalus and R. steindachneri. Journal of Aquaculture 13: 193-196.

19. Yu D, Zhang Z, Shen Z, Zhang C, Liu H (2018) Regional differences in thermal adaptation of a cold-water fish Rhynchocypris oxycephalus revealed by thermal tolerance and transcriptomic responses. Scientific Reports 8: 11703.

20. Zhang Z, Cheng Q, Ge Y (2019) The complete motochondrial genome of Rhynchocypris oxycephalus (Teleostei: Cyprinidae) and its phylogenetic implications. Ecology and Evolution 9(13): 7819-7837.

21. Park JS, Kim YS, Xi H (2019) The complete mitochondrial genome sequence of Chinese minnow in Korea, Rhynchocypris oxycephalus (Sauvage and Dabry de Thiersant, 1874). Mitochondrial DNA Part B 4(1): 662-663.

22. Park IS, Kim JH, Bang IC, Kim DS (1998a) Histological study of the early gonadal development and sexual differentiation in Rhynchocypris oxycephalus. Development and Reproduction 2: 69-74.

23. Kang YJ, Min MS (1999) Reproductive cycles of Moroco oxycephalus and M. lagowskii in Korea . Korean Journal of Ichthyology 11(2): 117-125.

24. Han KH, Noh BY, Oh SH, Park JT, Cho JK (1999) Early life history and spawning behavior of Chinese minnow, Rhynchocypris oxycephalus reared in the laboratory. Korean Journal of Ichthyology 11: 177-183.

25. Park IS, Kim JH, Lee JH, Kim CH (1999) Egg development of Rhynchocypris oxycephalus (Teleostei, Cyprinidae). Yellow Sea 5: 46-50.

26. Kang YJ, Min MS, Yang SY (2000) Reproductive isolation between Morco oxycephalus and M. lagowskii (Pisces; Cyprinidae) in Korea. Korean Journal of Biological Sciences 4(2): 109-115.

27. Park IS, Choi GC, Nam YK, Kim DS (2002) The effect of exogenous hormone treatment on spermiation in Rhynchopris oxycephalus (Sauvage and Dabry). Journal of World Aquaculture Society 33: 494-500.

28. Park IS (2002) Induction of ovulation by HCG, LHRHa and carp pituitary in Rhynchocypris oxycephalus (Sauvage and Dabry). Asian-Australasian Journal of Animal Sciences 15: 387-393.

29. Gwak JY, Park JY (2007) Structure of oocyte surface in two Korean minnow species, Rhynchocypris Kumgangensis and $R$. oxycephalus (Pisces: Cyprinidae). Korean Journal of Ichthyology 19(1): 16-23.
30. Kim DH, Chang BS, Jung HS, Teng YC, Kim S (2009) The Oogenesis of Chinese minnow, Leuciscinae, Teleostei. Korean Journal of Microbiology 39: 237-243.

31. Kim DH, Chang BS, Kim WJ, Lee MS, Teng YC (2010) The spermatogenesis of Chinese minnow, Leuciscinae, Teleostei. Korean Journal of Microbiology 40(1): 18

32. Kim HC, Kim MS, Y HS (1994) Biological control of vector mosquitoes by the use of fish predators, Morco oxycephalus and Misgurnus anguillicaudatus in the laboratory and semi-field rice paddy. Korean Journal of Applied Entomology 24: 269-284.

33. Yu D, Chen M, Zhou Z, Eric R, Tang Q (2013) Global climate change will severely decerase potential distribution of the East Asian coldwater fish Rhynchocypris oxycephalus (Actinopterygil, Cyprinidae). Hydrobiologia 700: 23-32

34. Nishida K, Koizumi N, Satoh T, Senga Y, Takemura T (2015) Influence of the domestic alien fish Rhynchocypris oxycephalus invasion on the distribution of the closely related native fish $R$. lagowskii in the Tana river basin. Japanese Journal of Land Eco Engineering 11: 169-176.

35. Lee S, Ahn CH, Song HM, Park JR, Joo JC (2017) Prey survival and vulnerability of juvenile Rhynchocypris oxycephalus in juvenile fish shelters under predation by Korean native piscivorous fish (Cpreoperca herzi). Water 9: 36 .

36. Lei J, Xiong W, Sui XY, Chen YF (2018) Feeding habits of the Chinese minnow Rhynchocypris oxycephalus (Sauvage \& Dabry de Thiersant, 1874) from the upper Yangtze river, China. Journal of Applied Ichthyology 34(3): 550-555.

37. Lee KK, Kim YH, Park IS (1999) Effect of starvation on some nutritional parameters in Rhynchocypris. 1. Characteristics of the histological and biochemical changes. Korean Journal of Ichthyology 11(1): 33-41.

38. Park IS, Im JH, Teong CH, Noh JK, Kim YH (2002) Effect of starvation on some nutritional parameters in Rhynchocypris oxycephalus (Sauvage and Dabry). 2. Characteristics of the morphometric changes in the sectioned body. Korean Journal of Ichthyology 14: 118.

39. Park IS (2004) Effect of starvation on some parameters in Rhynchocypris oxycephalus (Sauvage and Dabry): A review. Korean Journal of Environmental Biology 22(3): 351-368.

40. Park IS (2000) Vertebral column deformites in Rhynchocypris oxycephalus by cold shock treatment Journal of Fish Pathology 13: 147-151.

41. Park IS, Im JH, Cho SH (2004) Effect of dietary thyroxine and iodide on growth of Rhynchocypris oxycephalus (Sauvage and Dabry). Korean Journal of Ichthyology 16: 13-18.

42. Shin JA, Song JY, Lim HY, Chang MH, Lee HM (2006) An in vitro vitellogenin bioassay for estrogenic substances in the Rhynchocypris oxycephalus. Korean Journal of Veterinary Research 46(1): 35-41.

43. Jun I, Lim KM, Choi YH, Park DW, Keum DK (2010) The measurement of radionuclides concentration ratio of the aquatic animal using the Chinese minnow (Rhynchocypris oxycephalus). Journal of Korean Radioactive Waste Society 8(3): 215-220.

44. Park IS, Kim JH, Jung JB, Im JH (1998b) Effect of lidocaine as an anaesthetic on Rhynchocypris oxycephalus and $R$. steindachneri. Journal of Aquaculture 11: 59-66.

45. Park IS, Im JH, Kim JH, Kim DS (1998c) Wound healing of surgical incisions in Rhynchocypris oxycephalus. Journal of Aquaculture 11: 167172.

46. Park IS, Lim CH, Choi MS (1998d) The evaluation of lidocainehydrochloride as anaesthetic for the transportation of Rhynchocypris oxycephalus. Journal of Korean Fishery Society 31(6): 785-790. 


\section{Appendix}

Appendix 1: A review of publications for Chinese minnow, Rhynchocypris oxycephalus and Amur minnow, Rhynchocypris lagowskii.

\begin{tabular}{|c|c|c|}
\hline Item & Minnow species & References \\
\hline & Rhynchocypris oxycephalus & $\begin{array}{l}\text { Min \& Yang (1986) [13] } \\
\text { Yang \& Min (1988)[14] }\end{array}$ \\
\hline 1. Zootaxy & Rhynchocypris lagowskii & $\begin{array}{l}\text { Min \& Yang (1986)[13] } \\
\text { Yang \& Min (1988)[14] } \\
\text { Jean (1989)[15] } \\
\text { Yang \& Min (1989)[16] } \\
\text { Min \& Yang (1992)[17] } \\
\text { Park et al. (2000)[18] } \\
\text { Takai et al. (2012)[8] }\end{array}$ \\
\hline \multirow[t]{2}{*}{$\begin{array}{l}\text { 2. Reproduction \& } \\
\text { Development }\end{array}$} & Rhynchocypris oxycephalus & $\begin{array}{c}\text { Park et al. (1998a)[22] } \\
\text { Han et al. (1999)[24] } \\
\text { Kang \& Min (1999)[23] } \\
\text { Park et al. (1999)[25] } \\
\text { Kang et al. (2000)[26] } \\
\text { Gwak and Park(2007)[29] } \\
\text { Park et al. (2002)[27] } \\
\quad \text { Park (2002)[28] } \\
\text { Kim et al. (2009)[30] } \\
\text { Kim et al. (2010)[31] }\end{array}$ \\
\hline & Rhynchocypris lagowskii & $\begin{array}{l}\text { Kang \& Min (1999)[23] } \\
\text { Kang et al. (2000)[26] }\end{array}$ \\
\hline \multirow[t]{2}{*}{ 3. Ecology } & Rhynchocypris oxycephalus & $\begin{array}{l}\text { Kim et al. (1994)[32] } \\
\text { Yu et al. (2013)[33] } \\
\text { Liang et al. (2014)[9] } \\
\text { Yu et al. (2014)[11] } \\
\text { Nishida et al. (2015)[34] } \\
\text { Lee et al. (2017)[35] } \\
\text { Lei et al. (2018)[36] }\end{array}$ \\
\hline & Rhynchocypris lagowskii & Nishida et al. (2015)[34] \\
\hline 4. Starvation & Rhynchocypris oxycephalus & $\begin{array}{l}\text { Lee et al. (1999)[37] } \\
\text { Park et al. (2001)[4] } \\
\text { Park et al. (2002)[27] } \\
\text { Park (2004)[39] }\end{array}$ \\
\hline 5. Environmental biology & Rhynchocypris oxycephalus & $\begin{array}{l}\text { Park (2000)[40] } \\
\text { Park et al. }(2004)[41] \\
\text { Shin et al. }(2006)[42] \\
\text { Jun et al. }(2010)[43]\end{array}$ \\
\hline
\end{tabular}




\begin{tabular}{|l|c|c|}
\hline \multirow{2}{*}{ 6. Techniques } & & Park (1998b)[44] \\
Park et al. (1998c)[45] \\
Phynchocypris oxycephalus & Park et al. (1998d)[46] \\
\cline { 2 - 3 } & & Park et al. (1998b)[44] \\
& Rhynchocypris lagowskii & Park et al. (1998d)[46] \\
\hline
\end{tabular}

\section{ISSN: 2574-1241}

DOI: 10.26717/BJSTR.2021.34.005600

In-Seok Park. Biomed J Sci \& Tech Res

(C) (5) This work is licensed under Creative

Submission Link: https://biomedres.us/submit-manuscript.php

$\begin{array}{ll}\text { BIOMEDICAL } & \text { Assets of Publishing with us } \\ \text { RESEARCHES } & \text { Global archiving of articles } \\ \text { - Immediate, unrestricted online access }\end{array}$

